Eliya Putri Utami, Aldri Frinaldi I Efektivitas Penerapan Aplikasi SICANTIK di Dinas Penanaman Modal Pelayanan Terpadu Satu Pintu, Perindustrian dan Tenaga Kerja Kota Bukittinggi

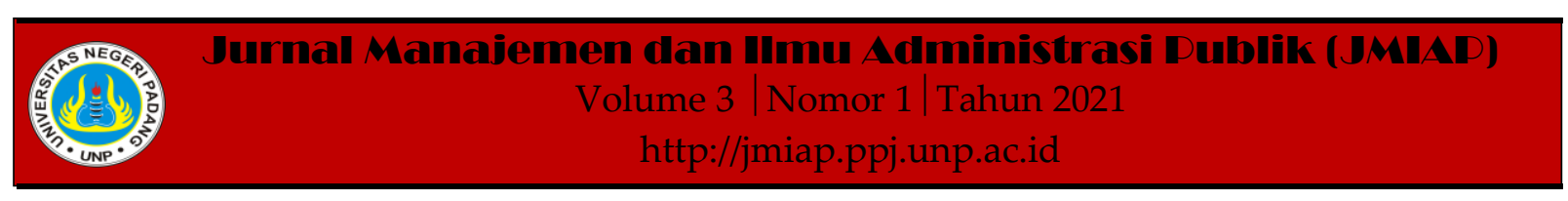

\title{
EFEKTIVITAS PENERAPAN APLIKASI SICANTIK DI DINAS PENANAMAN MODAL PELAYANAN TERPADU SATU PINTU, PERINDUSTRIAN DAN TENAGA KERJA KOTA BUKITTINGGI
}

\author{
Eliya Putri Utami ${ }^{1(a)}$, Aldri Frinaldi ${ }^{2(b)}$ \\ ${ }^{1}$ Jurusan Ilmu Administrasi Negara, Universitas Negeri Padang \\ ${ }^{2}$ Jurusan Ilmu Administrasi Negara, Universitas Negeri Padang \\ a)eliyaputriu@gmail.com, ${ }^{b)}$ aldri@fis.unp.ac.id
}

\begin{abstract}
This study aimed to determine the effectiveness of implementing the SICANTIK application in the One Stop Services Investment Office, Industry and Labor in the City of Bukittinggi. The SICANTIK application is an application that aims to provide services regarding licensing that are directly related to the community, and this is one of the government's efforts to provide quality public services to the community. This research is descriptive using qualitative methods. Informants were selected using purposive sampling technique. In data collection, research instruments were used in the form of field observations and interviews with several informants, then documentation study was used for documents in the study. The technique of testing the validity of the data used the triangulation method. While the data analysis technique is done by reducing data, displaying data and drawing conclusions from the research that has been carried out. The results of this study indicate that knowing the effectiveness of implementing the SICANTIK application in the One Stop Services Investment Office, Industry and Labor of the City of Bukittinggi is not effective enough.
\end{abstract}

Keywords : Effectiveness, Public Services, SICANTIK Applications

Corresponding author. Email. eliyaputriu@gmail.com

How to cite this article. Utami, E. Putri \& Frinaldi, A. (2021). Efektivitas Penerapan Aplikasi SICANTIK di Dinas Penanaman Modal Pelayanan Terpadu Satu Pintu, Perindustrian dan Tenaga Kerja Kota Bukittinggi. Jurnal Manajemen dan Ilmu Administrasi Publik (JMIAP) Jurusan Ilmu Administrasi Negara Fakultas Ilmu Sosial Universitas Negeri Padang, Volume 3 (1), Hal. 22-30.

http://jmiap.ppj.unp.ac.id

Copyright@2021. Published by Labor Jurusan Ilmu Administrasi Negara FIS UNP, Padang 


\section{PENDAHULUAN}

Pemanfaatan teknologi informasi merupakan suatu kebutuhan termasuk dalam proses penyelenggaraan pemerintahan. Menurut Forman (dalam Nugraha, 2018) Penerapan Sistem Informasi Manajemen dalam pemerintahan dikenal dengan istilah Electronic Government yang secara umum dapat diartikan sebagai pengguna teknologi informasi untuk mentransformasikan kegiatan pemerintahan yang tujuannya agar bisa meningkatkan efektivitas serta efisiensi penyelenggaraan pelayanan.

E-government menurut Indrajit (2006) diartikan sebagai mekanisme interaksi baru antara pemerintah dan stakeholder serta penyelenggara kepentingan lainnya, yang melibatkan manfaat dari perkembangan teknologi informasi yang bertujuan untuk meningkatkan kualitas pelayanan.

Aplikasi SICANTIK muncul setelah adanya Intruksi presiden nomor 3 Tahun 2003 yang berisi "Pengembangan Electronic Government ialah upaya agar pengembangan dalam menyelenggarakan kepemerintahan berbasis elektronik dalam rangka untuk peningkatan kualitas pelayanan publik agar mencapai tujuan yang di inginkan. Selanjutnya PP Nomor 97 Tahun 2014 yang berisi Penyelenggaraan Perizinan dan Non Perizinan oleh Pelayanan Terpadu Satu Pintu harus menggunakan pelayanan secara elektronik. Terpaut dengan Pelayanan terpadu satu pintu daerah dapat dijelaskan dalam Peraturan mentri dalam negri Nomor 138 Tahun 2017.Selain itu penerapan aplikasi SiCantik juga didukung dengan adannya implementasi OSS (online Single Submission) untuk daerah sesuai PP Nomor 91 Tahun 2017 tentang Percepatan Pelaksanaan Berusaha.

Aplikasi ini dikembangkan untuk memfasilitasi layanan perizinan yang transparan, efektif dan efisien. Berdasarkan informasi yang didapatkan dari Kabid Pelayanan Data, Pengaduan dan Pelaporan, permasalahan yang terjadi dalam proses penerapan aplikasi SiCantik adalah masih kurangnnya kesadaran masyarakat akan pentingnya penggunaan tekonologi informasi akibatnya masih banyak masyarakat yang belum bisa mengoperasikan aplikasi SICANTIK ini, Hal ini terkadang menyebabkan proses perizinan untuk penginputan data menjadi terhambat akibatnya proses perizinan akan memakan waktu lama, terkadang orang juga meminta bantuan kepada karyawan ketika tidak mengerti bagaimana cara menggunakannya.

Penerapan aplikasi SICANTIK seharusnya dapat mempercepat kinerja pegawai serta mempermudah masyarakat dalam pengurusan izin dan non perizinan,Namun kenyataannya hal ini belum terlaksana dengan baik karena masih banyak masyarakat yang tidak bisa mengoperasikan aplikasi tersebut,dengan alasan penggunaannya yang rumit,karena persyaratan yang di input terlalu banyak dan berbagai alasan lainnya.Akibat keterbatasan pemahaman yang bisa menggunakan aplikasi SICANTIK menyebabkan keterlambatan dalam menginput data perizinan maka proses perizinan tidak dapat diselesaikan dengan cepat sehingga menghambat tercapainnya sasaran pelayanan. Dengan adannya aplikasi SICANTIK diharapkan dapat meminimalisir kesalahan dalam penginputan data serta waktu persetujuan perizinan di terbitkan lebih efektif dan efisien.

Banyaknya masyarakat yang mengeluh karena sulitnya pengoperasian aplikasi SICANTIK diakibatkan karena masyarakat belum pernah mengikuti pelatihan tentang pengoperasian aplikasi SICANTIK,cara penggunaan aplikasi SICANTIK hanya pernah diadakan satu kali disaat pertama kali aplikasi ini diterapkan yaitu pada tahun 2018,itu pun hanya disosialisaikan kepada pegawai belum ke masyarakat yang ingin melakukan permohonan izin.

Semenjak adanya aplikasi SICANTIK ini muncul sudah banyak perubahan terhadap aplikasi dan aplikasi ini sudah banyak diperbaharui.Aplikasi SICANTIK 
telah mengalami 5 kali perubahan hingga ke tahap berbasis cloud saat ini.Sejak tahun 2018 sampai sekarang tentu sudah banyak masyarakat yang mengurus izin melalui aplikasi SICANTIK, sebagian masyarakat masih kesulitan dalam pengoperasian aplikasi ini.Sebelumnya pihak DPMPTSPPTK Kota Bukittinggi sudah memberitahui cara prosesnya melalui baliho dan radio, namun hal tersebut belum cukup untuk mengatasi permasalahan yang ada, masyarakat yang berusia lanjut mereka kesulitan untuk mempelajari tentang pemakaian aplikasi SICANTIK, jika hanya melihat prosesnya dibaliho saja ,terkadang mereka tidak melihat baliho tersebut.

Selanjutnya masih banyak masyarakat yang belum mengetahui penggunaan layanan perizinan yang bersifat online akibatnya masyarakat lebih cenderung langsung menggunakan cara yang konvensional yaitu dengan langsung mendatangi kantor dinas perizinan untuk mengajukan perizinan.Dengan tujuan jika menerapkan teknologi informasi dan komunikasi, pelayanan dengan keseluruhan bisa mencapai tujuan yang lebih baik, dengan adanya teknologi informasi dan komunikasi kendala jarak, pembiayaan serta waktu dapat menjadi lebih efektif. Kurangnya sosialisai kepada masyarakat tentang adannya aplikasi SICANTIK sehingga masih banyak juga yang belum tahu. Dengan Adanya aplikasi SiCANTIK diharapkan dapat menimalisir kesalahan dalam menginput data dan proses pengurusan perizinan bisa lebih efekif dan efisien.

\section{TINJAUAN PUSTAKA}

\section{Konsep Efektivitas}

Efektif berasal dari bahasa Inggris effective artinya suatu kegiatan yang dilakukan dapat mencapai tujuanmnya. Adapun keberhasilan suatu organisasi pada umumnya dapat diukur menggunakan konsep efektivitas terkait dengan pencpaian tujuan yang telah di tetapkan sebelumnya. Pasolong (2010: 3) menyebutkan bahwa efektivitas pada awalnya mucul dari kata istilah "efek", yang digunakan sebagai hubungan sebab dan akibat.

Menurut Ahmad Subekti (2013:247) efektivitas ialah hubungan antara output dan tujuan. Hal tersebut bisa di artikan efektivitas merupakan pengukuran terhadap sejauh apa tingkat dari output, kebijakan serta sebuah proses dari suatu organisasi agar bisa mencapai tujuan yang di inginkan.

Pendapat lain dikemukakan oleh Mahsun (2006:182) menyebutkan efektivitas merupakan sesuatu yang berkaitan dengan hubungan antara keluaran, serta apa tujuan atau sasaran yang hendak dicapai. Efektivitas sendiri pada dasarnya berkaitan dengan pencapaian suatu tujuan ataupun pencapain suatu kebijakan. Sebuah kebijakan operasional dapat terbilang efektif jika sebuah proses dari kegiatan itu bisa mencapai tujuan serta sasaran terakhir dari sebuah kebijakan.

Berikut beberapa kriteria yang dapat digunakan untuk mengukur sebuah efektivitas organisasi. Menurut Campbell (1989:121), adapun pengukuran efektivitas secara keseluruhan yang paling berpengaruh sebagai berikut :

1) Keberhasilan Progam

2) Kebershasilan Sasaran

3) Kepuasan terhadap Program

4) Tingkat input dan Ouput

5) Pencapaian tujuan menyeluruh

\section{Konsep Electronic Government}

Menurut Mustopadijaya (Achmad Habibullah 2010) menjelaskan electronic administration (e-adm) merupakan sebuah substitusi ungkapan electronic government (e-gov) yang dapat diberikan untuk sebuah pemerintaham dengan mengadopsi teknologi yang berbasis internet, dan dapat melengkapi serta meningkatkan suatu program dan pelayanan. Menurut Achmad (2010) mengungkapkan bahwa $E$ government ialah pemanfaatan serta pendayagunaan teknologi komunikasi serta informasi dalam rangka untuk mencapai bebarapa tujuan serta kebutuhan yang akan; a) Meningkatkan suatu efisiensi serta cost- 
efectiveness dari pemerintah; b) Memberikan suatu jasa pelayanan kepada para masyarakat dengan secara lebih baik; c) Menyediakan suatu akses informasi kepada public yang secara lebih luas; d) Menjadikan suatu penyelenggaraan pemerintah yang lebih bertanggung jawab serta transparan kepada masyarakat.

\section{Konsep Sistem Informasi Manajemen}

Menurut Raymond (2008:12) Sistem Informasi Manajemen ialah suatu sistem yang berhubungan dengan computer sehingga dapat membuat suatu informasi yang bisa di dapatkan oleh para pengguna sesuai dengan kebutuhannya. Sistem informasi manajemen merupakan salah satu ilmu yang cukup terdampak akibat perkembangan teknologi. Secara sederhana sistem informasi manajemen ialah sebuah sistem berbasis komputer yang dapat digunakan untuk menghasilkan suatu informasi dari data yang sudah diinput dan diolah sebelumnya (Aldri, 2014).

Dalam kondisi dan situasi saat ini terdapat berbagai bentuk sistem informasi, Menurut Abdul Kadir dalam Fahmi 2016, terdapat beberapa macam sistem informasi, sebagai berikut; 1) suatu sistem yang reservasi pesawat terbang; 2) suatu sistem untuk menangani penjualan tiket dan kendaraan bermotor; 3) suatu sistem yang biometrik; 4) suatu sistem POS (poin of sale); 5) suatu sistem yang telemetri atau pemantauan jarak jauh; 6) sistem yang berbasis kartu cerdas (smardcard); 7) sistem tersebut dipasang pada tempat public; 8) suatu sistem layanan akademis dengan menggunakan web; 9) $E$ government dan sistem informasi layanan pemerintah yang menggunakan jaringan internet.

\section{Konsep Pelayanan Publik}

Pelayanan publik menurut Sinambela (2008, h.5) di artikan sebagai sebuah aktifitas pemerintah kepada masyarakat untuk menjalin suatu kegiatan serta hasil nya bukan hanya selalu bentuknya barang tetapi juga jasa.

Menurut Sinambela (2008) pada dasar nya tujuan dari pelayanan publik ialah memberikan kepuasan terhadap masyarakat. Dalam mencapai kepuasan tersebut diharuskan kualitas pelayanan prima yang dapat dilihat dari :

1) Transparansi

2) Akuntabilitas

3) Kondisional

4) Partisipatif

5) Kesamaan hak

6) Keseimbangan hak dan kewajiban

\section{Kendala dalam Mengefektifkan Penerapan Aplikasi SICANTIK}

Menurut Hasen dan Mowen (dalam Selviana dan Setya, 2016:23) dapat dikelompokan jenis dari kendala yakni merupakan kendala Internal dan Eksternal.

\section{METODE PENELITIAN}

Jenis dari Penelitian ini merupakan penelitian kualitatif dengan pendekatan deskriptif. Penelitian sendiri dilakukan pada DPMPTSPPTK Kota Bukittinggi. Penentuan informan dilakukan dengan purposive sampling yaitu teknik penentuan informan dengan pertimbangan tertentu yang dianggap dapat memberikan data secara maksimal. Informan dalam penelitian ini antara lain beberapa orang pegawai DPMPTSPPTK dan masyarakat yang paham dan terlibat dalam penerapan aplikasi SICANTIK.

Untuk pengumpulan data tersebut pada penelitian ini ialah berbentuk data primer dan sekunder. Data dikumpulkan melalui wawancara dengan beberapa pegawai di DPMPTSPPTK Kota Bukittinggi, untuk data yang didapatkan dengan cara melakukan suatu observasi (pengamatan) wawancara serta studi dokumentasi. Uji keabsahan suatu data penelitian tersebut ialah dengan menggunakan metode triangulasi, Sedangkan untuk teknik analisis data tersebut dapat dilakukan dengan 
mereduksi data, display data, serta bisa menarik kesimpulan dari penelitian yang telah dilakukan.

\section{HASIL DAN PEMBAHASAN \\ Keberhasilan Program}

Menurut Campbel

$(1989: 121)$

keberhasilan sebuah program bisa dilihat dari kualitas program itu sendiri, apakah sudah berjalan dengan maksimal atau belum. Berdasarkan hasil penelitian aplikasi SICANTIK sudah berhasil diterapkan di DPMPTSPPTK Kota Buktitinggi.Hal ini dilihat dari semenjak diterapkannya aplikasi ini dari tahun 2018 sampai sekarang dengan lima kali perubahan versi,penerapan aplikasi SICANTIK juga diterima di DPMPTSPPTK serta mendapat dukungan dari pegawai karena sangat membantu dalam proses perizinan.

Dalam proses pelaksanannya,aplikasi SICANTIK tidak mudah digunakan oleh masyarakatdalam pengurusan izin.Hal ini dapat dibuktikan dengan masih banyaknya masyarakat yang tidak bisa menggunakan aplikasi SICANTIK di DPMPTSPPTK Kota Bukititinggi, Hal ini disebabkan masyarakat belum mengetahui secara khusus pengoperasian aplikasi SICANTIK.Untuk memaksimalkan penerapan aplikasi SICANTIK di DPMPTSPPTK Kota Bukititinggi telah dilakukan berbagai upaya salah satunya dengan melihat dari baliho atau internet,serta meminta bantuan dari pegawai yang bisa mengoperasikan aplikasi SICANTIK, namun hal tersebut masih belum membantu,sebab ada beberapa pemohon yang berusia lanjut sehingga mereka membutuh waktu yang tidak sebentar untuk bisa paham cara pengoperasian aplikasi SICANTIK.

Dari uraiaan diatas dapat disimpulkan bahwa aplikasi SICANTIK sudah berhasil diterapkan di DPMPTSPPTK Kota Bukittinggi sejak tahun 2018,tetapi di dalam pelaksanaannya masih cukup banyak masyarakat yang belum bisa menggunakan aplikasi SICANTIK, akibatnya dalam proses penginputan data kadang terjadi keterlambatan.

\section{Keberhasilan Sasaran}

Indikator kedua untuk mengukur efektivitas program adalah keberhasilan sasaran. Menurut Campbell (1989:121), keberhasilan sasaran dapat dilihat dengan difokuskan kepada output dari suatu program.Untuk mencapai sasaran yang telah ditetapkan ,dari hasil penelitian yang telah dilakukan,Penerapan aplikasi SICANTIK sangat membantu masyarakat dalam pengurusan izin hingga menghasilkan penerbitan izin yang akurat dan transparan.Dengan adannya aplikasi SICANTIK seluruh proses perizinan dan non perizinan dapat diketahui melalui informasi yang disampaikan lewat SMS GateAway,sehingga seluruh proses izin pelaksanaannya dapat dapat diproses dengan cepat menggunakan aplikasi SICANTIK.Pengurusan izin mlalui aplikasi ini dapat meminimalisir kesalahan dalam menginput data serta meminimalisir waktu.Dengan adannya aplikasi SICANTIK semua pelayanan proses izin dari tahun ke tahun terus meningkat serta dapat diakses kapan pun dan dimanapun.

Berdasarkan hasil penelitian dari teori yang digunakan dapat disimpulkan bahwa penerapan aplikasi SICANTIK sangat membantu pegawai dan masyarakat dalam mencapai sasarannya untuk menghasilkan penerbitan izin dengan cepat dan akurat.Aplikasi SICANTIK tidak hanya bermanfaat bagi pengguna atau pemohon yang melakukan perizinan dan non perizinan juga sanagat bermanfaat bagi pihak DPMPTSPPTK dan DISKOMINFO selaku pengawa dan penanggungjawab aplikasi SICANTIK.Dengan adannya aplikasi SICANTIK pemohon tidak perlu lagi datang langsung ke kantor DPMPTSPPTK Kota Bukittinggi untuk memeriksa sudah sejauh mana proses izin pemohon di proses,karena dapat diakses kapan saja dan dimana saja oleh pemohon. 


\section{Kepuasan Terhadap Program}

Indikator ketiga untuk mengukur efektivitas program adalah kepuasan terhadap program. Menurut Campbell (1989:121), kepuasan terhadap program dapat dilihat dari bagaimana kepuasan pengguna terhadap kualitas dari barang atau jasa yang dihasilkan dari sebuah program. Menurut temuan peneliti terungkap bahwa keberhasilan sebuah sasaran penerapan aplikasi SICANTIK ini sudah mulai tercapai Hal ini dapat dilihat dari semua menu dan fitur yang terdapat dalam aplikasi SICANTIK sudah bisa memenuhi kebutuhan masyarakat dalam proses pengurusan izin.Dari segi keamananya, Data yang di input kedalam aplikasi SICANTIK dijamin aman,sebab untuk mengakses data di aplikasi SICANTIK kita harus login menggunakan user name adan pasword yang kita dapatkan sebelumnya dari registrasi melalui email pemohon.Sehingga tidak bisa orang lain mengubah data di aplikasi SICANTIK untuk pengaksesannya,tidak semua menu yang ada di dalam aplikasi SICANTIK dapat diakses oleh pemohon,sebagian menu hanya khusus digunakan oleh Admin SICANTIK.

Berdasarkan hasil penelitian dari teori yang digunakan,kepuasan pengguna tehadap aplikasi SICANTIK sudah bisa dikatakan cukup puas karena seluruh menu dan fitur yang ada pada aplikasi SICANTIK bermanfaat bagi masyarakat yang akan melakukan permohonan izin dan memberikan kemudahan dalam pengurusannya,masyarakat merasa sedikit kerumitan akibatnnya banyaknya persyaratan yang harus diupload dalam proses penginputan data,pemohon harus lebih teliti dan memahami setiap kode bagian-bagian yang di lampirkan agar tidak terjadi kesalahan dalam mengnput data.

\section{Tingkat Input dan Output}

Indikator keempat untuk mengukur efektivitas suatu program adalah tingkat input dan output. Menurut Campbell (1989:121), suatu program dapat dikatakan berhasil jika output yang dihasilkan lebih baik daripada input sebuah program.Untuk hal ini sendiiri tergantung bagaimana input input mempengaruhi output dari sebuah program sebagaimana DPMPTSPPTK dalam hal ini telah berupaya untuk mencapai sebuah tujuan dengan bisa menerima input yang besar sehingga output yang di inginkan bisa dicapai.Hal ini dapat dilihat dari fasilitas yang ada saat ini sudah cukup optimal.Seperti persyaratan,prosedur maupun pembiayaan,prosedur SOP sehingga jelas dan ,pelayanan yang diberikan berjalan secara optimal.Dalam pengurusan izin harus dilakukan sesuai dengan prosedur dan persyaratan yang diminta.Input dari proses pengurusan izin adalah keluhan yang diterima oleh pihak DPMPTSPTK Kota Bukittinggi atau pihak penyelenggara sehingga memberikan kemudahan bagi pemohon,Sedangkan outputnya adalah pelayanan yang diberikan oleh pihak penyelenggara dan masyarakat yang merasakan hasil dari pelayanan tersebut.

\section{Pencapaian Tujuan Menyeluruh}

Indikator terakhir untuk mengukur efektivitas program adalah pencapaian tujuan menyeluruh. Menurut Campbell (1989:121), pencapaian sebuah tujuan secara menyeluruh dapat dinilai dari sejauh apa suatu organisasi dapat melaksanakan tugasnya untuk mencapai suatu sasaran. Sehingga efektivitas sebuah program bisa berjalan berdasarkan dengan kemampuan operasionalnya dalam pelaksanaan sebuah program yang dijalankan sesuai dengan tujuan yang sudah ditetapkan sebelumnya secara komprehensif, efektivitas bisa diartikan sebuah tingkat dari kemampuan suatu lembaga agar bisa mencapai sasarannya yang sesuai dengan telah ketentuan sebelumnya.

Menurut penelitian yang sudah peneliti laksanakan, bisa diketahui bahwasannya secara keseluruhan pencapaian tujuan dari program penerapan aplikasi SICANTIK sudah mulai tercapai. Hal ini bisa dilihat dari pencapaian tujuan yang sudah 
ditetapkan seperti yang sudah dikemukakan sebelumnya. Dalam penerapan aplikasi SICANTIK adapun tujuan yang ingin dicapai yaitu mempermudah pemerintah dalam memberikan pelayanan kepada masyarakat,mempermudah masyarakat dalam pengurusan izin,serta mempersingkat waktu dan biaya dalam pengurusan izin oleh pemohon,dengan adannya tujuan yang telah ditentukan efektivitas penerapan aplikasi SICANTIK dapat diukur dari seberapa jauh tujuan yang ditentukan sudah tercapai saat ini.

Dari wawancara yang peneliti lakukan, dapat dipahami bahwa pencapaian tujuan secara menyeluruh dari penerapan aplikasi SICANTIK sudah cukup efektif.Hal ini dilihat dari jumlah masyarakat yang mengurus izin secara online lumayan banyak dibandingkan datang secara konvensional.Disini dapat dilihat bahwa pencapaiaan tujuan secara menyeluruh dari aplikasi SICANTIK diharapkan bisa mempermudah masyarakat dalam mengurus izin sehingga tujuan untuk meminimalisir waktu dan biaya tercapai.

\section{Kendala Dalam Penerapan Aplikasi SICANTIK di Dinas Penanaman Modal Pelayanan Terpadu Satu Pintu, Perindustrain dan Teaga Kerja Kota Bukittinggi}

Penerapan Aplikasi SICANTIK ialah salah satu program yang diterapkan di DPMPTSPPTK Kota Bukittinggi yang bertujuan untuk memudahkan masyarakat dalam melakukan pengurusan izin,dalam hal ini dengan penggunaaan aplikasi SICANTIK masyarakat bisa lebih mudah, dan praktis untuk mengurus perizinan dan non perizinan.

Tetapi di dalam pelaksanaanya ada berbagai macam kendala yang harus diatasi, dikurangkan ataupun dapat dicegah oleh pihak yang berwenang dalam hal tersebut ialah DPMPTSPPTK Kota Bukittinggi.Menurut Cox dan Schelier dalam selviana dan Setya ( $2016: 268$ ) menyebutkan theori Of Constrains atau yang dikenal dengan TOC. TOC didefenisikan sebagai sebuah pendekatan pada arah peningkatan sebuah proses yang terfokus terhadap elemen yang memiliki batasan kinerja dalam meningkatan output.Hansen dan Mowen dalam Selviana dan Setya ( 2016 : 23 ) membagi jenis kendala berdasarkan internal dan eksternal.

\section{Kendala Internal}

Berdasarkan hasil dari penemuan penelitian dapat dilihat bahwasannya kendala yang terjadi dalam penerapan aplikasi SICANTIK adalah gangguan jaringan atau server SICANTIK yang eror sehingga pemohon yang sedang melakukan pengurusan izin terhenti sementara dan proses perizinanya menjadi sedikit lama.

Berdasarkan teori yang sudah dikemukakan oleh Hansen dan Mowen dalam Selviana dan Setya ( 2016:23 ) menyebutkan bahwa kendala internal ( internal Constraint ) merupakan faktor yang membatasi suatu perusahaan atau sebuah organisasi serta sistem yang berasal dari dalam perusahaan.Untuk penerapan aplikasi SICANTIK ini kendala yang terjadi dari dalam organisasi merupakan gangguan jaringan atau server SICANTIK yang eror sehingga pemohon yang sedang melakukan pengurusan izin terhenti sementara dalam proses perizinannya sehingga membuat penerbitan surat izin sedikit lama.

\section{Kendala Eksternal}

Dapat Dilihat berdasarkan hasil temuan peneliti mengungkapkan bahwasannya kendala eksternal dari penerapan aplikasi SICANTIK adalah kesadaran masyarakat yang masih rendah untuk menggunakan aplikasi ini,terlihat dari antrian di kantor DPMPTSPPTK Kota Bukittinggi masih banyak pemohon yang memilih datang secara konvensional.

Berdasarkan teori yang sudah dikemukakan oleh Hansen dan Mowen dalam Selviana dan Setya ( $2016: 23$ ) menyebutkan bahwa kendala eksternal ( Eksternal Constainst ) merupakan suatu hal yang membatasi sebuah perusahaan yang dapat terjadi dari luar perusahaan ataupun 
bisa diartikan yang berasal dari luar sebuah organisasi.

\section{PENUTUP}

Menurut penelitian serta pembahasan yang sudah peneliti lakukan, maka peneliti dapat mengambil kesimpulkan sebagai berikut :

1. Penerapan aplikasi SICANTIK sudah terlaksana dengan baik, namun dalam penerapnnya masih terdapat berbagai kendala yang sangat berpengaruh dalam proses pelaksanaan sehingga masih belum cukup untuk dikatakan efektif. Sesuai dengan teori pengukuran efektivitas menurut Campbell yang digunakan dalam penelitian ini bahwa keberhasilan sebuah program, keberhasilan sebuah sasaran, tingkatan input serta output dalam mencapai tujuan secara keseluruhan melalui penerapan aplikasi SICANTIK sudah dapat dirasakan oleh semua pihak. Namun untuk kepuasan pengguna masih belum maksimal karena masih ada keluhan dari masyarakat saat mengoperasikan aplikasi SICANTIK, juga masih banyak masyarakat yang tidak bisa mengoperasikan Aplikasi SICANTIK . Untuk mengatasi masalah tersebut hendaknya dilakukan sosialisasi pelatihan atau penyuluhan dan peningkatan kualitas pengguna agar aplikasi SICANTIK dapat dimanfaatkan dengan baik dan optimal.

2. Kendala-kendala dalam penerapan aplikasi SICANTIK ini adalah kurangnnya kesadaran masyarakat dalam melakukan pengurusan izin melalui aplikasi SICANTIK dan masih banyak masyarakat yang belum paham cara penggunaan dan pengoperasian proses perizinan melalui aplikasi SICANTIK sehingga membuat proses perizinan menjadi sedikit lama.

\section{DAFTAR KEPUSTAKAAN}

Aldri, Frinaldi. (2014). Sistem Informasi Manajemen. Fakultas Ilmu Sosial Universitas Negeri Padang.

Campbell. 1989. Riset Dalam Efektivitas Organisasi. Terjemahan Sahat Simamora. Jakarta: Erlangga.

Frinaldi,A.,dkk ( 2020 ).E-Goverment as intervening of work culture to increase internal customer satisfaction.International journal of payschosocial Rehabilitation. Vol. 24

Habibullah, Achmad. (2010). Kajian Pemanfaatan dan Pengembangan $E$ Government. Jurnal administrasi Negara, Vol. 23, No. 3, 2010. Jember.

Indrajit, Richardius Eko. (2006). Elektronik Government. Yogyakarta : Andi.

Indrajit, Richardus Eko (2004). EGovernment Strategi Pembangunan Dan Pengembangan Sistem Pelayanan Publik Berbasis Teknologi Digital. Yogyakarta:Andi Offset.

Mahsun, Mohamad. 2006. Pengukuran Kinerja Sektor Publik. Yogyakarta: BPFE-Yogyakarta.

Moleong, Lexy J. 2005. Metode Penelitian Kualitatif (edisirevisi). Bandung: PT. Remaja Rosdokarya.

Pasolong, Harbani. (2010). Teori Administrasi Publik. Bandung: Alfabeta.

Raymond Mcleod.2008.Sistem Informasi Manajemen. Jakarta : Salempa Empat.

Selviana Putri Larasati, Setya Haksama. 2016. Penerapan Theory of Constraint Pada Kepuasan Kerja Karyawan Rumah Sakit Mata Undaan Surabaya. Jurnal Administrasi Kesehatan Indonesia Vol. 4 No. 2. 
Eliya Putri Utami, Aldri Frinaldi I Efektivitas Penerapan Aplikasi SICANTIK di Dinas Penanaman Modal Pelayanan Terpadu Satu Pintu, Perindustrian dan Tenaga Kerja Kota Bukittinggi

Sondang P. Siagian. (1983). Bungo Rampai

Manajemen Modern (pp32-35).

Jakarta: Gunung Agung.

Perpres No.97 tahun 2014. Tentang

Penyelenggaraan pelayanan terpadu satu pintu. Jakarta : Republik Indonesia

Perpres No.91 tahun 2017. Tentang

Percepatan Pelaksanaan

Berusaha.Jakarta : Republik Indonesia.

Permendagri No.138 tahun 2017. Tentang

Penyelenggaraan Pelayanan Terpadu

Satu Pintu Daerah. Jakarta. 